\title{
A Study on Entrepreneurial Intention of University Students in Bangladesh
}

\author{
Samia Shabnaz ${ }^{1} \&$ Nazrul Islam ${ }^{2}$ \\ ${ }^{1}$ Faculty of Business Administration, American International University-Bangladesh, Dhaka, Bangladesh \\ ${ }^{2}$ Faculty of Business, Northern University Bangladesh, Dhaka, Bangladesh
}

Correspondence: Samia Shabnaz, Faculty of Business Administration, American International University-Bangladesh, House \# ka-66/1, Kuril, Kuratoli Road, Khilkhet, Dhaka-1229, Bangladesh.

Received: July 29, 2021

Accepted: August 27, 2021

Online Published: August 31, 2021

doi:10.5539/ibr.v14n10p13

URL: https://doi.org/10.5539/ibr.v14n10p13

\begin{abstract}
Entrepreneurial intention is the function of motives and barriers encountered by the university students during their studies. As the unemployment rate among the university graduates is the highest in Bangladesh, the research focused on university students with the aim to predict their entrepreneurial behaviors. Previous studies identified different environmental contexts of the countries have different influence on the perception regarding motives and barriers of entrepreneurial intention of the students. Hence, to stimulate the development of entrepreneurship, it is important to uncover university student's perceptions regarding the motives and barriers to develop entrepreneurship and their influences on entrepreneurial intention of the graduates. To conduct the research, the primary data were collected from 398 business students using simple random sampling method through self-administered questionnaire. Descriptive statistics were used to analyze the demographic profiles of the respondents. A multivariate statistical technique like Factor Analysis was used to identify the factors influencing entrepreneurial intention and Regression Analysis was used to predict the significant impact factors. It is evident in the study that the driving factors like autonomy and market opportunity has significant positive impact whereas barriers like financial and government support, lack of skills has significant negative impact on the student's entrepreneurial intentions. This paper will assist the policy makers, educational institutions and researchers to develop several implementable strategies like enterprise education, liberal tax system, financial and regulatory support to promote entrepreneurship in a developing country like Bangladesh.
\end{abstract}

Keywords: entrepreneurial Intention, motives and barriers, autonomy, market opportunity, government support, entrepreneurial education

\section{Introduction}

\subsection{Background}

Developing countries are concentrating more on entrepreneurship as it provides innovation, generates new employment opportunities, and leads to increased economic and social wealth in the country. In the context of Bangladesh, 0.39 million unemployed person with tertiary education are youth from the age group of 15 to 29 (LFSB, 2016-17). Educated youth has the potential to contribute to the socio-economic progress of the country. Youth entrepreneurship promotion may solve the problem of unemployment as traditional career opportunities are declining for young people who face a labor market crisis. Several researchers (Sharma \& Madan, 2014, Gree \& Thurnik, 2003, Turker \& Selcuk, 2009) recognized youth entrepreneurship as the key for building prosperity and stimulating regional growth. Van Gelderen, Brand, Van Praag, Bodewes \& Van Gils, (2008) stated that in the entrepreneurship process, entrepreneurial intentions are significant since they form the foundation of new business. According to Henley's (2007) opinion, entrepreneurship intention is formed at least a year before the new venture creation. Thus university graduates are the latest concentration of research as it forecasts their entrepreneurial behaviors in the future. On the other hand the literature reveals that entrepreneurial intent, triggers, and barriers are potentially important factors of the entrepreneurial process (Schlaegel, Engle, Dimitriadi, \& Taureck, 2015). However, very few in-depth studies have been conducted on university student's perception of motivating and impeding factors of entrepreneurship especially in the context of Bangladesh. It is critical to determine their entrepreneurial intention and impact of the motives and barrier on the intentions to start-up a business in future which will solve the problem of graduate employability. The objectives of the study 
are as follows.

- To determine the entrepreneurial intention of Bangladeshi University students;

- To identify the motivating and restricting factors that can influence the entrepreneurial intention of the Bangladeshi University students.

- To explore the impacts of motives and barriers on the entrepreneurial intentions of Bangladeshi University students.

\subsection{Literature Review}

The process of graduates starting business as an individual career orientation refers to as graduate entrepreneurship (Rwigema \& Venter, 2004). According to Pihie (2009) there are two different ways to measure entrepreneurship. One way is to measure the initiative of people who have actually started business refers to as actual entrepreneurship. Another way is to measure the activity of people that intend to start business refers to as entrepreneurial intention or latent entrepreneurship. This study focused on latent entrepreneurship. The researcher also noted that intention is the state of mind or attitude which influences entrepreneurial behavior. Wong \& Choo (2009) claimed intention as the single best predictor of entrepreneurial behavior. Entrepreneurship intention is a conscious state of mind that leads individual to a specific direction to achieve it (Vesalainen \& Pihkala, 2000). Pihie (2009) pointed out that intentionality deals with perceptive psychology that attempts to forecast human behavior and the behavioral intention results from immediate determinant of behavior and attitudes. Researchers argued that entrepreneurial intention is the prime indicator of future entrepreneurial behavior (Van Gelderen et al., 2008, Wong \& Choo, 2009). Ajzen (1991) argues that a person's attitude towards behavior (a personal desire to become self-employed), subjective norm, and perceived behavioral control (the perception of the easiness or difficulty in the fulfillment of the behavior) are the significant factors that determine his intentions. According to the process driven theory developed by Bandura (1986), individual's perception of the ability to perform the planned action determines the behavior. The theory also indicated that the external environment affect thoughts which shapes attitude and form intention. If the intention is strong enough then it leads one to action.

Ashley-Cotleur, King \& Solomon (2009) identified number of specific factors that stimulate a person's decision to become an entrepreneur. The factors are classified as demographic variables like gender, family background, previous employment story, education, religion, ethnic membership or attitudes, values and psychological factors like need for achievement, risk-taking propensity, locus of control, tolerance of ambiguity and the desire for personal control. Several studies concluded that a blend of psychological traits interacting with background factors makes some individuals more entrepreneurial than others (McClelland 1961, Brockhaus, 1980, Brockhaus, 1982, Scherer, Brodzinsky \& Wiebe, 1991, Greenberger \& Sexton, 1988).

According to Reynolds et al., (2005) and Acs, (2006), reasons or motives can be classified as either opportunity ("pull") or necessity ("push"). Several researchers identified internally driven motives (pull factor) as positive motivators and externally driven motives (push factors) as negative motivators because they influence individual's involvement in entrepreneurship (McGregor \& Tweed, 2000, Still \& Soutar, 2001, DeMartino \& Barbato, 2003, Shamim, 2008, Kirkwood, 2009, Eijdenberg \& Masurel, 2013). They also revealed that entrepreneurs in least developed countries are more forced by their external environment than entrepreneurs in developed countries. However, in the study which was done on SME owners in Vietnam by Swierczek \& Ha, 2003, it is evident that challenges and achievements were more significant motivator than necessity and security. Carter, Gartner, Shaver \& Gatewood, (2003) revealed that the financial security is the most widely held motivating factor in United Nation. However, increasing income and self-employment generation works as important motivating factor for entrepreneurs of developing countries like Kenya and Ghana (Chu, Benzing \& McGee, 2007).

Individual's perception of barriers to new venture creation has negative relation with entrepreneurial intentions (Pittaway \& Cope, 2007, Mamun, Nawi, Mohiuddin, Shamsudin \& Fazal, 2017, Sitaridis \& Kitsios, 2018). Several researchers classified the obstacles to entrepreneurial intention into exogenous or external factors if they are influenced by environmental factors and endogenous or internal factors if the deriving source is the individual (Ledyaeva, Gustafsson-Pesonen, Mochnikova, \& Vasilenko, 2008, Ooi and Ahmad, 2012, Sesen \& Pruett 2014; Stamboulis \& Barlas 2014). According to Sitaridis \& Kitsios (2019) the most influential barriers proved to be those of knowledge, skills, time and risk, whereas Giacomin et al. (2011) found lack of support structure, financial and administrative costs were rated as most significant.

From the literature review focused on university students indicated that employment and autonomy are the 
common and most important motivators whereas lack of capital, lack of skill and risk taking propensity are the common and greatest obstacle of entrepreneurial intention (Fatoki, 2010, Fatoki, 2014, Memon, et. al. 2015, Şeşen, \& Pruett, 2014, Sitaridis \& Kitsios 2018, Iakovleva, et. al. 2014). However, a study on Malaysian postgraduate students found that the intrinsic factors such as aversion to risk and fear of failure had weaker and significant effects than extrinsic ones like lack of social networking (Sandhu, Sidique, \& Riaz, 2011). The triggers like educational support, environmental support, family and network support showed stronger effects on entrepreneurial intent compared to the barriers such as fear of failure, lack of environmental support, lack of family and network support, lack of skills training, and knowledge. Individuals in different countries are similarly triggered and perceive similar barriers to venture creation, while different levels of sensitivity to these triggers as well as barriers exist (Schlaegel, et. al 2015).

Chowdhury (2007) investigated the constraints that entrepreneurs face in small and medium enterprises (SMEs) in Bangladesh and found that the political stability, rule of law, infrastructural facilities, corruption, education and training, financial help are the major limitations for the development of SMEs. The study done by Islam, (2009), identified major obstacles for small scale trading enterprises formation which includes start-up capital, location, business knowledge, business experience, family members, skilled employees, training, etc. In another research Minton (2006) reported that absence of a properly functioning capital and bond market and lack of long term capital availability through banking channels limits the growth of entrepreneurship in this country. The study done on the apparel export industry of Bangladesh by Quddus \& Rashid (2000) indicated that entrepreneurs in Bangladesh had to face a myriad of bureaucratic obstacles while starting their business. Most of these studies stressed obstructing factors for the entrepreneurs who initiated small scale enterprise yet there is not enough comprehensive approach to identifying constraints of entrepreneurial intention of the students in Bangladesh. A summary of motives and barriers of entrepreneurial intension of university is shown in Table 1.

Table 1. Literature on motives and barriers of entrepreneurial intention

\begin{tabular}{|c|c|c|c|}
\hline Study & Motives & Barriers & Sample \\
\hline Fatoki, 2010 & $\begin{array}{l}\text { Employment (E), Autonomy (I), } \\
\text { Creativity (I), Macro-Economy (E), } \\
\text { Capital (E) }\end{array}$ & $\begin{array}{l}\text { Lack of Capital (E), Lack of Skill (I), } \\
\text { Government Support (E), Risk (I),The } \\
\text { Market Opportunity (E) }\end{array}$ & $\begin{array}{l}\text { Student } \\
\text { South Africa }\end{array}$ \\
\hline Fatoki, 2014 & $\begin{array}{l}\text { Financial Challenge }(\mathrm{E}) \\
\text { Independence (I) }\end{array}$ & Lack of Finance (E) & $\begin{array}{l}\text { Student ent } \\
\text { South Africa }\end{array}$ \\
\hline $\begin{array}{l}\text { Memon, Makhdoom, } \\
\text { Shah \& Tunio, } 2020\end{array}$ & $\begin{array}{l}\text { Employment (E), Autonomy (I), } \\
\text { Creativity (I), Macro-Economy (E), } \\
\text { Capital (E) }\end{array}$ & $\begin{array}{l}\text { Lack of Capital (E), Lack of Skill (I), } \\
\text { Government Support (E), Risk (I), The } \\
\text { market opportunity (E) }\end{array}$ & $\begin{array}{l}\text { Student } \\
\text { Pakistan }\end{array}$ \\
\hline Şeşen, \& Pruett, 2014 & $\begin{array}{l}\text { Pursuit of Profit and Social Status } \\
\text { (E), Desire for Independence (I), } \\
\text { Creation (I), Personal Development } \\
\text { (I), Professional Dissatisfaction (E) }\end{array}$ & $\begin{array}{l}\text { Lack of Support Structure And Fiscal or } \\
\text { Administrative Costs (E), Lack of } \\
\text { Knowledge \& Experience (I), } \\
\text { Economic Climate And Lack of } \\
\text { Entrepreneurial Competencies (E), Lack } \\
\text { Of Self-Confidence (I), Risk Aversion (I) }\end{array}$ & $\begin{array}{l}\text { Student USA } \\
\text { Turkey }\end{array}$ \\
\hline Sitaridis \& Kitsios, 2018 & Self-motivation (I) & $\begin{array}{l}\text { Knowledge And Skills (I), Time And Risk } \\
\text { (I), Regulation Constraints (E), Market } \\
\text { Constraints (E), Financial Constraints (E) }\end{array}$ & $\begin{array}{l}\text { IT Student } \\
\text { Greece }\end{array}$ \\
\hline $\begin{array}{l}\text { Moustafa \& Refaat, } \\
2016\end{array}$ & $\begin{array}{l}\text { Autonomous and Independent (I) } \\
\text { Achieving Self-Esteem (I) Create } \\
\text { Personal Wealth (E) }\end{array}$ & $\begin{array}{l}\text { Excessive Risk (I), The Bureaucracy (E), } \\
\text { Lack of Source of Finance (E) }\end{array}$ & $\begin{array}{l}\text { Student } \\
\text { Egypt }\end{array}$ \\
\hline Neneh, 2014 & $\begin{array}{l}\text { Unemployment (E), Poverty (E), Job } \\
\text { security (E) }\end{array}$ & $\begin{array}{l}\text { Lack of Fund (E), Lack of Business Skill } \\
\text { (I), Bribery And Corruption (E), Strong } \\
\text { Competitor (E), High Tax \& High Labor } \\
\text { Cost (E) }\end{array}$ & $\begin{array}{l}\text { Student } \\
\text { Cameroon }\end{array}$ \\
\hline Ooi and Ahmad, 2012 & $\begin{array}{l}\text { Intrinsic Rewards (I) Extrinsic } \\
\text { Rewards (E), Independence/ } \\
\text { Autonomy (I), Family Security (E) } \\
\text { And Change Management (I) }\end{array}$ & $\begin{array}{l}\text { Exogenous Factors (E), Endogenous } \\
\text { Factors (I) Financial And Operational } \\
\text { Constraints (E). }\end{array}$ & $\begin{array}{l}\text { Student } \\
\text { Malaysia }\end{array}$ \\
\hline $\begin{array}{l}\text { Fatoki, and Chindoga, } \\
2011\end{array}$ & & $\begin{array}{l}\text { Lack of Capital (E), Lack of Skill (I), } \\
\text { Government Support (E), Risk (I), The } \\
\text { market opportunity (E) }\end{array}$ & $\begin{array}{l}\text { Student South } \\
\text { Africa }\end{array}$ \\
\hline $\begin{array}{l}\text { Iakovleva, Kolvereid, } \\
\text { Gorgievski, \& Sørhaug, } \\
2014\end{array}$ & & $\begin{array}{l}\text { Lack of Money (E), Lack of Skill (I), Risk } \\
\text { Perception (I) }\end{array}$ & $\begin{array}{l}\text { Student } \\
\text { Europe }\end{array}$ \\
\hline $\begin{array}{l}\text { Thanh, Hau, Huyen, } \\
\text { Linh, Doanh, \& Nga, } \\
2020\end{array}$ & & $\begin{array}{l}\text { Personal Traits (I), Cognitive Conditions } \\
\text { (I), Normative (E) And Regulative } \\
\text { Structures (E) }\end{array}$ & $\begin{array}{l}\text { Student } \\
\text { Vietnam }\end{array}$ \\
\hline
\end{tabular}




\begin{tabular}{|c|c|c|c|}
\hline Study & Motives & Barriers & Sample \\
\hline $\begin{array}{l}\text { Amanamah, Owusu \& } \\
\text { Acheampong, } 2018\end{array}$ & & $\begin{array}{l}\text { Economic(E), Legal(E), } \\
\text { Socio-Cultural(E), Personal (I) }\end{array}$ & $\begin{array}{l}\text { Student } \\
\text { Ghana }\end{array}$ \\
\hline Schlaegel, et. al. 2015 & $\begin{array}{l}\text { Educational Support (E), } \\
\text { Environmental Support (E), Family } \\
\text { and Network Support (E) }\end{array}$ & $\begin{array}{l}\text { Fear of Failure (I), Lack of Environmental } \\
\text { Support(E), Lack of Family And } \\
\text { Network Support (E), Lack of Skills } \\
\text { Training Knowledge(I) }\end{array}$ & $\begin{array}{l}\text { Ent Germany } \\
\text { Russia, USA }\end{array}$ \\
\hline $\begin{array}{l}\text { Zimmerman and Chu, } \\
2013\end{array}$ & Own Boss (I), Increase Income (E) & $\begin{array}{l}\text { Competition (E), A Weak Economy(E), } \\
\text { Foreign Exchange Limitations (E) }\end{array}$ & Ent Venezuela \\
\hline Kirkwood, 2009 & $\begin{array}{l}\text { Independence (I), Money (E), Desire } \\
\text { for Challenge (I), Opportunity in the } \\
\text { Market (E), Lifestyle/Family (E) }\end{array}$ & $\begin{array}{l}\text { Job dissatisfaction (E), Changing World } \\
\text { of Work (E), Helped by Employer (E), } \\
\text { Children (E) }\end{array}$ & $\begin{array}{l}\text { Ent } \\
\text { Newzeland }\end{array}$ \\
\hline $\begin{array}{l}\text { Benzing, chu \& McGee, } \\
2007\end{array}$ & $\begin{array}{l}\text { Security (E), Income (E), } \\
\text { Independence (I), Intrinsic (I) }\end{array}$ & $\begin{array}{l}\text { Market Problem (E), Lack of Business } \\
\text { Training (E), Location Problem (E), } \\
\text { Governmental Problem (E), } \\
\text { Infrastructural Problem (E) }\end{array}$ & SME, Turkey \\
\hline $\begin{array}{l}\text { Amouri, Sidrat, } \\
\text { Boudabbous, } \\
\text { Boujelbene, } 2016\end{array}$ & $\begin{array}{l}\text { Government Policy And Procedure } \\
\text { (E), Socio-Economic Conditions (E), } \\
\text { Entrepreneurial Skills (I), Financial } \\
\text { and Non-Financial Assistance (E). }\end{array}$ & & $\begin{array}{l}\text { Ent } \\
\text { Tunesia }\end{array}$ \\
\hline $\begin{array}{l}\text { Sidrat, Amouri, } \\
\text { Boujelbene, \& } \\
\text { Boudabbous, } 2016 \\
\end{array}$ & & $\begin{array}{l}\text { Lack Of Managerial And Business Skills } \\
\text { (I), Poor Training Programs (E), Risk } \\
\text { Aversion (I). }\end{array}$ & $\begin{array}{l}\text { Ent } \\
\text { Tunesia }\end{array}$ \\
\hline Islam 2009 & $\begin{array}{l}\text { Money (E), Independence (I), skill } \\
\text { (I), Unemployment (E) }\end{array}$ & $\begin{array}{l}\text { Lack of Capital (E), Infrastructural } \\
\text { Problem (E), Lack of Skills Training, \& } \\
\text { Knowledge (I), Lack of Family \& } \\
\text { Network Support (E), Lack of Skilled } \\
\text { Employees (E) }\end{array}$ & $\begin{array}{l}\text { Ent } \\
\text { Bangladesh }\end{array}$ \\
\hline Chowdhury, 2007 & & $\begin{array}{l}\text { Regulative Structures (E) Infrastructural } \\
\text { Facilities (E), Lack of Skills Training, } \\
\text { And Knowledge(I), Lack of Capital (E) }\end{array}$ & $\begin{array}{l}\text { Ent } \\
\text { Bangladesh }\end{array}$ \\
\hline
\end{tabular}

I=Intrinsic, E= Extrinsic, Ent $=$ Entrepreneurs

\subsection{Development of Hypotheses and Their Correspondence to Research Design}

Several studies were done on the entrepreneurial intention of graduates which focused mainly on developed countries (Frank, Korunka, Leuger \& Mugler, 2005, Turker \& Selcuk 2009, Ismail, et. al. 2009). Barbosa \& Moraes (2004) argued that conclusions regarding entrepreneurial intention may differ in developing countries because of the environmental differences. Benzing, Chu \& McGee (2007), Eijdenberg \& Masurel (2013) observed the motivating factors which differs across countries due to difference in income level and employment opportunity however few researches have been done in developing countries like Bangladesh. Pruett, Shinnar, Toney, Llopis \& Fox (2009) and Giacomin et al. (2011) indicated that cultural differences between nations generate major variations in the perceptions of motives, barriers and entrepreneurial intentions. Empirical research done regarding entrepreneurial intention has identified several important motives and barriers to start-ups. However, very few focused on country specific variables of developing country. The studies done in the context of Bangladesh (Chowdhury, 2007, Islam, 2009) focused on the constraints of small scale enterprises which might be different from the student's perception of barriers. Moreover, the majority of studies on motives and barriers have been descriptive. In order to fill this gap, this study empirically investigated different types of motives and barriers to entrepreneurship by assessing perception of undergraduate students and determined their influence on entrepreneurial intention. Based on literature review, the following hypotheses were developed in this study.

H1: There is a significant impact of autonomy on entrepreneurial intentions of the university students in Bangladesh.

H2: There is a significant impact of financial and government support on entrepreneurial intentions of the students.

H3: There is a significant impact of lack of entrepreneurial skills on entrepreneurial intentions of the students.

H4: There is a significant impact of market opportunity on entrepreneurial intentions of the students.

H5: There is a significant impact of legal and regulatory framework on entrepreneurial intentions of the students. 


\section{Research Methods}

\subsection{Characteristics of the Respondents}

The population of the study has been selected based on certain criteria. The study targeted students of BBA program from a public and a private university of Dhaka city. The demographic profile of the respondents from the study is summarized in Table 2. The descriptive analysis indicated representation from male and female student $67.8 \%$ and $32.3 \%$ respectively, and $66.3 \%$ of the respondents belong to the age group of 19-22 years and $33.7 \%$ from $23-26$ years. The study indicated that the majority of the respondents family has $1-4$ members (54\%), $45.3 \%$ respondent's family income is 51000-100000 and a large number of respondents have no income (69.5\%).

Table 2. Demographic profiles of the respondent students

\begin{tabular}{|c|c|c|c|c|c|c|}
\hline \multicolumn{7}{|c|}{ Sample size, $(n=398)$} \\
\hline \multirow[t]{2}{*}{ Gender } & Male & $67.8 \%$ & & $\begin{array}{l}\text { Fathers } \\
\text { occupation }\end{array}$ & \multicolumn{2}{|c|}{ Mother's Occupation } \\
\hline & Female & $32.3 \%$ & private & $27.5 \%$ & $8 \%$ & \\
\hline \multirow[t]{2}{*}{ Age } & $19-22$ & $66.3 \%$ & public & $25.3 \%$ & $6.8 \%$ & \\
\hline & $23-26$ & $33.7 \%$ & Self-employed & $44.3 \%$ & $9.3 \%$ & \\
\hline \multirow[t]{2}{*}{ University type } & Private & $84.5 \%$ & unemployed & $3 \%$ & $76 \%$ & \\
\hline & Public & $15.5 \%$ & \multicolumn{2}{|l|}{ Career Intention } & & \\
\hline \multirow[t]{2}{*}{ Family size } & $1-4$ & $54 \%$ & \multicolumn{2}{|l|}{ Start a Business } & \multicolumn{2}{|l|}{$20 \%$} \\
\hline & $5+$ & $46 \%$ & \multicolumn{2}{|l|}{ Seek Job } & \multicolumn{2}{|c|}{$38.3 \%$} \\
\hline \multirow[t]{3}{*}{ Family income } & $<50000$ & $28 \%$ & \multicolumn{2}{|l|}{ Higher Studies } & \multicolumn{2}{|c|}{$35.8 \%$} \\
\hline & $51000-100000$ & $45.3 \%$ & \multicolumn{2}{|l|}{ Not yet Decided } & \multicolumn{2}{|l|}{$6 \%$} \\
\hline & $100000+$ & $26.8 \%$ & \multirow{2}{*}{\multicolumn{2}{|c|}{ Entrepreneurial family member }} & Yes & $68 \%$ \\
\hline \multirow{3}{*}{$\begin{array}{l}\text { Respondents } \\
\text { Income }\end{array}$} & No income & $69.5 \%$ & & & No & $32 \%$ \\
\hline & $<10000$ & $18.5 \%$ & \multirow{2}{*}{\multicolumn{2}{|c|}{ University programs encourages Ent }} & Yes & $79.3 \%$ \\
\hline & $10000+$ & $12 \%$ & & & No & $20.8 \%$ \\
\hline \multirow{2}{*}{$\begin{array}{l}\text { Business } \\
\text { Experience }\end{array}$} & Yes & $29.3 \%$ & \multirow{2}{*}{\multicolumn{2}{|c|}{ University program support Ent. }} & Yes & $75.5 \%$ \\
\hline & No & $70.8 \%$ & & & No & $24.5 \%$ \\
\hline
\end{tabular}

In the study majority of the business students responded from private university of Dhaka city. Very few students have business experience (29.3\%) and want to start business as career choice $(20 \%)$ whereas majority of the students have intention to seek job (38.3\%) and higher studies $(35.8 \%)$ after graduation. On the other hand a large number of respondent's have their father's occupation as self-employment, have entrepreneurial family members who encourages them to become entrepreneur and believes that university program encourages and give support for entrepreneurship.

\subsection{Research Design}

\subsubsection{Sample size}

According to the UGC Annual Report 2019, the number of student studying business in private and public universities of Bangladesh is 87695 and 41090 respectively. The total population is 128785 . The sample size was calculated at 95\% confidence level which comprised of 398 undergraduate business students (Yamane, 1967). Probability sampling simple random sampling was used for time and cost convenience. The sample was selected from randomly chosen universities of Dhaka city. As it is an exploratory research and there are common characteristics (age, academic background, career intention) exists among the business students, the sampling method is appropriate for the research. Therefore, it is expected that the results obtained are reliable and representative of the population.

\subsubsection{Data Source}

The primary data has been collected through questionnaire survey where all questions were closed-ended and respondents were asked to tick according to their perception. 500 questionnaires were distributed during the class session of undergraduates with the approval and cooperation of faculty members among them 400 response were usable. The data was collected during the month of March 2020. Secondary data was collected from several reports, books, journals, conference papers. Extensive literature review has been done analyzing the papers of academicians and practitioners published in renowned international journals, namely PROQUEST, EMERALD, 
EBSCO, IEEE, ACM, JSTOR, Springer, Science Direct, etc.

\subsubsection{Measures}

The study used a structured questionnaire to determine entrepreneurial intention and the influence of motives and barriers on entrepreneurial intention of university students using a 5 point Likert scale $(1=$ strongly disagree, and $5=$ strongly agree) for data collection. The self-structured questionnaire was divided into four parts. The first part was designed to record the demographic information and the second part contained 9 items which aims at measuring respondent intention to be involved in entrepreneurial function. Part 3 contained 23 statements to identify the driving forces of each respondent's to become an entrepreneur and part 4 contained 37 statements related to barriers for entrepreneurial intention. The instrument was adopted from similar studies of Fatoki, (2010) and Neneh, (2014).

\subsubsection{Data Analysis Techniques}

Statistical software SPSS version 20 was used to analyze the data. Descriptive statistics were used to examine the demographic profile of students and Cronbach's alpha were used to measure reliability. Multivariate statistical technique like factor Analysis was used to reduce variables. The analysis identified the significant factors that influence the young graduates entrepreneurial intention. The relationships with the variables were identified using regression analysis.

\section{Results}

\subsection{Exploratory Factor Analysis}

Two indicators were examined to assess the appropriateness of the sample for conducting exploratory factor analysis. The Kaiser Meyer-Olkin measure of sampling adequacy index was .882 and Bartlett's test of sphericity was significant, i.e., $\mathrm{p}<.0001$, indicating that the sample and correlation matrix were appropriate for the analysis (Malhotra, 2008, p.642). The motives and barriers for university students to become entrepreneur consisted of 69 items after conducting focus group discussions and literature reviews. The study used Principal Axis Factoring (PAF) to identify factors. Factor solutions were determined based on eigenvalues of 1.0 or greater, factor loadings of .50 or greater and simple structure (Comrey \& Lee, 1992). Results indicated 6 factors with eigenvalues of 1.0 or greater (utilizing the Kaiser rule). During the analysis, varimax orthogonal rotation was conducted and produced the clearest factor structure. Thirty four items were dropped due to low factor loadings or dual-loading. These procedures resulted in a 35-item instrument that accounted for 59.452\% of the variance.

The first factor consisted of 9-items, accounted for $23.329 \%$ of the variance, and was labeled as entrepreneurial intention. It contained items that measured the level of intention to become entrepreneur. The second factor included 6 items, accounted for $14.103 \%$ of the variance, and was characterized as autonomy which is also evident in the research of Fatoki, (2010), Şeşen, \& Pruett, (2014) and Moustafa, (2016). It contained items that reflected the degree to which a student was concentrating on independence, satisfaction and growth, enjoyment, prestige and status and realization of dreams. It is seen that all variable in this factor have loading values greater than $60 \%$ which means these variables are satisfactory to explain the first factor. The finding also complements the research of DeMartino and Barbato (2003) and Shamim (2008) where the researchers pointed out the internally driven motive to become self-employed is evident among the youth of Bangladesh. The third factor contained 7 items, accounted for $7.382 \%$ of the variance and was labeled as financial and government support. It included items like high tax and labor cost, strong competition, lack of collateral and saving, strict government regulation where factor loadings of the variables have values greater than $50 \%$. These factors work as obstruction for entrepreneurial intention for students of Bangladesh which is also evident in the research of Ooi \& Ahmed (2012) as exogenous factors. The forth factor had 5 items, accounted for 5.802\% of the variance, and was declared as lack of skill. The factor included variables such as lack of business experience, Lack of entrepreneurial education, Lack of knowledge about business plan, lack of planning and lack of business skill. This factor is also evident in the research of Fatoki, \& Chindoga (2011) and Fatoki, (2010) with significant impact on entrepreneurial intention. The Fifth factor accounted for $4.954 \%$ of the variance, named as market opportunity which is an extrinsic factor. The items included are opportunities in the market, good economic condition, earn a reasonable living and maintain family. The external environmental factor works as a motivation for the Bangladeshi youth which is in line with the finding of Kirkwood (2009). The sixth factor accounted for $3.882 \%$ of the variance and categorized as legal and regulatory framework which consisted of 3 items. The factor indicated the lack of confidence in the legal and regulatory framework of the country which includes law and order situation, bureaucracy, bribery and corruption. According to Thanh, et al. (2019), Amanamah, et. al., (2018) Chowdhury, (2007), legal and regulatory framework significantly hinders the growth of entrepreneurship in the country. The reliability of each set of items was measured using Cronbach's alpha. The Cronbach's alpha ranged 
between 0.727 and 0.916 , exceeding the suggested cut-off value of 0.70 (Nunnally \& Bernstein, 1994).

Table 3. Rotated Factor Matrix

\begin{tabular}{|c|c|c|c|c|c|}
\hline Construct & & Measurement Item & $\begin{array}{l}\text { PAF } \\
\text { loading } \\
(n=400)\end{array}$ & $\begin{array}{l}\% \text { of } \\
\text { variance } \\
\text { explained }\end{array}$ & Eigenvalue \\
\hline \multirow{9}{*}{$\begin{array}{l}\text { Entrepreneurial } \\
\text { Intention } \\
\text { (Cronbach's } \alpha= \\
0.916)\end{array}$} & 1 & Put every effort to start and run my own business & .785 & \multirow{9}{*}{$23.329 \%$} & \multirow{9}{*}{7.932} \\
\hline & 2 & $\begin{array}{l}\text { Prefer to be an entrepreneur rather than an employee } \\
\text { in a company }\end{array}$ & .765 & & \\
\hline & 3 & Goal is to become an entrepreneur & .728 & & \\
\hline & 4 & Prepared to do something to become an entrepreneur & .722 & & \\
\hline & 5 & To be my own boss & .685 & & \\
\hline & 6 & Have strong intention to start a business someday & .681 & & \\
\hline & 7 & No doubt about ever starting a business & .671 & & \\
\hline & 8 & $\begin{array}{l}\text { Qualification contributed positively to the interest of } \\
\text { starting a business }\end{array}$ & .635 & & \\
\hline & 9 & $\begin{array}{l}\text { Had strong intention to start own business before } \\
\text { starting qualification }\end{array}$ & .604 & & \\
\hline \multirow{6}{*}{$\begin{array}{l}\text { Autonomy } \\
\text { (Cronbach's } \alpha= \\
0.859)\end{array}$} & 1 & To be Independent & .818 & \multirow{6}{*}{$14.103 \%$} & \multirow{6}{*}{4.795} \\
\hline & 2 & To be my own boss & 669 & & \\
\hline & 3 & For my own satisfaction and growth & .663 & & \\
\hline & 4 & To enjoy myself & .598 & & \\
\hline & 5 & To increase my prestige and status & .553 & & \\
\hline & 6 & Realize my dreams & .544 & & \\
\hline \multirow{7}{*}{$\begin{array}{l}\text { Financial and } \\
\text { government } \\
\text { support } \\
\text { (Cronbach's } \alpha= \\
0.834 \text { ) }\end{array}$} & 1 & High Tax & .718 & \multirow{7}{*}{$7.382 \%$} & \multirow{7}{*}{2.510} \\
\hline & 2 & Strong competitor & 690 & & \\
\hline & 3 & High labor cost & .611 & & \\
\hline & 4 & Strict government regulation & .605 & & \\
\hline & 5 & lack of government support & .535 & & \\
\hline & 6 & Lack of assets for collateral & .531 & & \\
\hline & 7 & lack of saving & .516 & & \\
\hline \multirow{5}{*}{$\begin{array}{l}\text { Lack of Skill } \\
\text { (Cronbach's } \alpha= \\
0.829)\end{array}$} & 1 & Lack of entrepreneurial education & .754 & \multirow{5}{*}{$5.802 \%$} & \multirow{5}{*}{1.973} \\
\hline & 2 & do not know how to write a business plan & .723 & & \\
\hline & 3 & Lack of business experience & .666 & & \\
\hline & 4 & lack of planning and long sighted & .656 & & \\
\hline & 5 & Lack of business skills (financial, marketing) & .612 & & \\
\hline \multirow{4}{*}{$\begin{array}{l}\text { Market } \\
\text { Opportunity } \\
\text { (Cronbach's } \alpha= \\
0.765 \text { ) }\end{array}$} & 1 & Opportunity in the market & .621 & \multirow{4}{*}{$4.954 \%$} & \multirow{4}{*}{1.684} \\
\hline & 2 & Good economic condition & .609 & & \\
\hline & 3 & To maintain my family & .577 & & \\
\hline & 4 & Earn a reasonable living & .568 & & \\
\hline \multirow{3}{*}{$\begin{array}{l}\text { Legal and } \\
\text { regulatory frame } \\
\text { work } \\
\text { (Cronbach's } \alpha= \\
0.727 \text { ) }\end{array}$} & 1 & Law and order situation & .659 & \multirow[b]{3}{*}{$3.882 \%$} & \multirow[b]{3}{*}{1.320} \\
\hline & 2 & Bureaucracy & .637 & & \\
\hline & 3 & Bribery and Corruption & .573 & & \\
\hline
\end{tabular}

Extraction method : Principal Axis Factoring (PAF)

a. Rotation converged in 7 iterations.

\subsection{Regression Analysis}

The study was conducted to determine if various factors of motives and barriers can influence students' entrepreneurial intention. The dependent variable entrepreneurial intention was regressed on predicting variables of autonomy, financial and government support, lack of skill, market opportunity, Legal and regulatory frame work. Table 4 shows the summery of the finding. The independent variables significantly predict entrepreneurial intention, $\mathrm{F}(5,354)=33.539, \mathrm{p}<.001$, which indicates that the five factors under study have a significant impact on 
entrepreneurial intention. Looking at the unique individual contribution of the predictors, the result shows that autonomy $(\beta=.438, \mathrm{t}=8.561, \mathrm{p}=.000)$ and market opportunity $(\beta=.214, \mathrm{t}=4.153, \mathrm{p}=.000)$ has positive impact on entrepreneurial intention. However the factors like financial and government support $(\beta=-.107, t=-2.027, p=.043)$ and lack of skills $(\beta=-.132, \mathrm{t}=-2.934, \mathrm{p}=.004)$ negatively influence entrepreneurial intention. It is also evident that the legal and regulatory framework does not significantly contribute to entrepreneurial intention of students. Moreover, the $\mathrm{R}^{2}=0.312$ depicts that the model explains $31.2 \%$ of the variance in entrepreneurial intention. Rest of the variance can be explained by socio economic and cultural variable which was not included in the current study. Further in-depth study should add these variables to get higher score in model fit for entrepreneurial intention.

Table 4. Regression Analysis

\begin{tabular}{cccccc}
\hline Hypothesis & Regression Weight & Beta coeffient & t-value & p-value & $\begin{array}{c}\text { Hypothesis } \\
\text { supported }\end{array}$ \\
\hline $\mathrm{H}_{1}$ & $\mathrm{Au}->$ EI & .438 & 8.561 & .000 & Yes \\
\hline $\mathrm{H}_{2}$ & FGS->EI & -.107 & -2.027 & .043 & Yes \\
\hline $\mathrm{H}_{3}$ & $\mathrm{SK}->\mathrm{EI}$ & -.132 & -2.934 & .004 & Yes \\
\hline $\mathrm{H}_{4}$ & $\mathrm{MO}->\mathrm{EI}$ & .214 & 4.153 & .000 & Yes \\
\hline $\mathrm{H}_{5}$ & $\mathrm{LR}->\mathrm{EI}$ & .030 & .579 & .563 & \\
\hline $\mathrm{R}^{2}$ & .312 & & & & \\
\hline $\mathrm{F}(5,354)$ & 33.539 & & & &
\end{tabular}

Note: $* \mathrm{p}<0.05, \mathrm{Au}=$ Autonomy, $\mathrm{FGS}=$ financial and government support, $\mathrm{SK}=$ lack of skill, $\mathrm{MO}=$ market opportunity, LR=legal and regulatory framework.

\section{Discussions}

Micro level economic growth can be achieved by entrepreneurship because it creates a continuous and feasible employment for individuals and substantially contribute in the country's GDP. The purpose of this study was to explore the relationship between entrepreneurial intentions and perceptions of motives and barriers. The results of the study identified five factors where autonomy (intrinsic) and market opportunity (extrinsic) works as driving factor. The finding is consistent with the research done on both developing and developed countries regarding the factor autonomy (Fatoki, 2010, Şeşen \& Pruett, 2014, Moustafa, 2016, Kirkwood, 2009, Islam 2009). However, many research done on developing countries indicated employment (Fatoki, 2010, Neneh, 2014, Islam 2009) as one of the major determinant which was partially attributed in the significant factor of market opportunity identified in this study. The identified barriers for entrepreneurial intention include financial and government support (extrinsic), lack of skill (intrinsic), Legal and regulatory frame work (extrinsic). The finding also complemented the earlier researches of Fatoki, (2010), Neneh, (2014), Fatoki \& Chindoga, (2011), Sitaridis $\&$ Kitsios (2018) which was done on the context of developing country. The regression analysis revealed that motivating factors positively and barriers negatively influence entrepreneurial intention. The model indicates that the legal and regulatory framework does not significantly contribute to entrepreneurial intention of students which is inconsistent with the finding of the studies done on the developing countries (Chowdhury, 2007, Neneh, 2014, Sitaridis\& Kitsios 2018). It has been observed that the intrinsic factors influence more than the extrinsic factors which has an important implication for education. For youth entrepreneurship development universities can play a vital role by influencing students to select their career as entrepreneur.

\section{Conclusions and Recommendations}

The study contributed to the research of entrepreneurial intentions focusing on the university student's perceptions of motives and barriers to entrepreneurship. It is evident that the internal barriers have a more influence on students Entrepreneurial intentions than the external ones. The most influential barriers identified are the perceived lack of skills. According to Giacomin et al. (2011) entrepreneurship education programs must be adjusted to the perceived barriers and motives to be efficient. Education can build confidence and skills of the students which can encourage students' motives and decrease their barrier perceptions to enhance entrepreneurial intentions. This study will be able to grab the attention of the curriculum development unit to design and develop 
practical oriented entrepreneurship education to stimulate student's interest in starting business. On the other hand awareness program regarding facilities available for graduate entrepreneur, capital availability, incentives and integrated support services, positive governmental regulation regarding tax can also reduce the student perception of barriers which will grow graduate entrepreneurship.

Despite the contribution this paper has some limitations which cannot be overlooked. The study concentrated on the potential entrepreneurs' perception of motives and barriers to entrepreneurship which might differ from the actual scenario encountered by the business graduates who have initiated business. However, it did not highlight the relationship of demographic variable and the students' perception. The scope was narrowed to Dhaka city because of time and budget limitations. Further research can be done adding socio-economic variables with balanced representation of sample from all over the country to observe the impact on entrepreneurial intention. On the other hand, the young entrepreneurs who have started their businesses after graduation can also be investigated to find any difference in their perception of motives and barriers.

\section{References}

Acs, Z. J. (2006). How is entrepreneurship good for economic growth? Innovations, 1(1), 97-107. https://doi.org/10.1162/itgg.2006.1.1.97

Ajzen, I. (1991). The theory of planned behavior. Organizational Behavior and Human Decision Processes, 50(2), 179-211. https://doi.org/10.1016/0749-5978(91)90020-T

Amanamah, R. B., Owusu, E. K., \& Acheampong, A. (2018). Barriers to entrepreneurial intention among university students in Ghana. European Journal of Research and Reflection in Educational Sciences, 6(1).

Amouri, A., Sidrat, S., Boudabbous, S., \& Boujelbene, Y. (2016). Effects of the Entrepreneurial Environment on Tunisian Individuals' Decision to Start a Business. International Journal of Humanities and Social Science Invention, 5(4), 52-59.

Ashley-Cotleur, C., King, S., \& Solomon, G. (2009). Parental and gender influences on entrepreneurial intentions, motivations and attitudes. George Washington University.

Bandura, A. (1986). Social foundations of thought and action-A social cognitive theory. Englewood Cliffs, NJ: Prentice-Hall.

Benzing, C., Chu, H. M., \& McGee, C. (2007). Ghanaian and Kenyan enterprises: a comparative analysis of their motivations, success, characteristics and Problems. Journal of Development Entrepreneurship, 12(3), 295-312. https://doi.org/10.1142/S1084946707000691

Brockhaus, R. H. (1980). Risk taking propensity of entrepreneurs. Academy of Management Journal, 23(3), 509-520. https://doi.org/10.2307/255515

Brockhaus, R. H. (1982). The psychology of the entrepreneur. Encyclopedia of entrepreneurship. CA Kent, DL Sexton and KH Vesper.

Carter, N. M., Gartner, W. B., Shaver, K. G., \& Gatewood, E. J. (2003). The career reason of nascent entrepreneur. Journal of Business Venturing, 18(1), 13-39. https://doi.org/10.1016/S0883-9026(02)00078-2

Chowdhury, M. S. (2007). Overcoming entrepreneurship development constraints: the case of Bangladesh. Journal of Enterprising Communities: People and Places in the Global Economy, 1(3), 240-251. https://doi.org/10.1108/17506200710779549

Chu, H. M., Benzing, C., \& McGee C. (2007). Ghanaian and Kenyan Entrepreneurs: A Comparative Analysis of their Motivations, success characteristics and problems. Journal of Developmental Entrepreneurship, 12(3), 295-322. https://doi.org/10.1142/S1084946707000691

Comrey, A. L., \& Lee, H. B. (1992). A First Course in Factor Analysis (2nd ed.). Hillsdale, NJ: L.

DeMartino, R., \& Barbato, R. (2003). Differences between women and men MBA entrepreneurs: Exploring family flexibility and wealth creation as career motivators. Journal of Business Venturing, 18(6), 815-832. https://doi.org/10.1016/S0883-9026(03)00003-X

Eijdenberg, E. L., \& Masurel, E. (2013). Entrepreneurial Motivation in a Least Developed Country: Push Factors and Pull Factors among MSEs in Uganda. Journal of Enterprising Culture, 21(1), 19-43. https://doi.org/10.1142/S0218495813500027

Fatoki, O. (2014). Student entrepreneurs on university campus in South Africa: motivations, challenges and entrepreneurial intention. Mediterranean Journal of Social Sciences, 5(16), 100. 
https://doi.org/10.5901/mjss.2014.v5n16p100

Fatoki, O. O. (2010). Graduate Entrepreneurial Intention in South Africa: Motivations and Obstacles. International Journal of Business and Management, 5(9), 87-98. https://doi.org/10.5539/ijbm.v5n9p87

Fatoki, O. O., \& Chindoga, L. (2011). An investigation into the obstacles to youth entrepreneurship in South Africa. International Business Research, 4(2), 161-169. https://doi.org/10.5539/ibr.v4n2p161

Frank, H., Korunka, C., Leuger, M., \& Mugler, J. (2005). Entrepreneurial orientation and education in Austrian secondary schools. Journal of Small Business and Enterprise Development, 12(2), 259-273. https://doi.org/10.1108/14626000510594647

Giacomin, O., Janssen, F., Pruett, M., Shinnae, R., Llopis, F., \& Toney B. (2011). Entrepreneurial intentions, motivations and barriers: differences among American, Asian and European students. International Entrepreneurship and Management Journal, 7(2), 219-238. https://doi.org/10.1007/s11365-010-0155-y

Gree, A., \& Thurnik, C. (2003). Firm selection and industry evolution: the post country performance of new firm. Journal of Evolutionary Economics, 4(4), 243-264.

Greenberger, D. B., \& D. L. Sexton (1988). An interactive model of new venture initiation. Journal of Small Business Management, 3(1), 1-7.

Henley, A. (2007). From entrepreneurial aspiration and transition to business startup: evidence from British longitudinal data. Entrepreneurship and Regional Development, 19(3), 253-280. https://doi.org/10.1080/08985620701223080

Iakovleva, T. A., Kolvereid, L., Gorgievski, M. J., \& Sørhaug, Ø. (2014). Comparison of perceived barriers to entrepreneurship in Eastern and Western European countries. International Journal of Entrepreneurship and Innovation Management, 18(2-3), 115-133. https://doi.org/10.1504/IJEIM.2014.062874

Islam, S. (2009). Start-up and growth constraints on small-scale trading in Bangladesh. Journal of Chinese Entrepreneurship, 1(3), 227-239. https://doi.org/10.1108/17561390910999515

Ismail, M., Khalid, S. A., Othman. M., Jusoff, H. K., Rahman. N. A., Kassim. K. M., \& Zain. R. S. (2009). Entrepreneurial intention among Malaysian undergraduate. International Journal of Business and Management, 4(10), 54-60. https://doi.org/10.5539/ijbm.v4n10p54

Kirkwood, J. (2009). Motivational factors in a push-pull theory of entrepreneurship. Gender in Management: An International Journal. https://doi.org/10.1108/17542410910968805

Labor Force Survey Bangladesh (LFSB). (2016-17). Bangladesh Bureau of Statistics, Statistics And Informatics Division, Ministry of Planning. Retrieved from http://203.112.218.65:8008/WebTestApplication/userfiles/Image/LatestReports/LFS_2016-17.pdf

Ledyaeva, S., Gustafsson-Pesonen, A., Mochnikova, E., \& Vasilenko, D. (2008). Russian students' perceptions of entrepreneurship. Results of a survey in three St.Petersburg universities, HSE Mikkeli Business Campus Publications; No. N-83.

Malhotra, N. K. (2008). Satyabhushan Dash. Marketing Research: An Applied Orientation. 5th International edition.-US: Pearson Education.

Mamun, A. A., Nawi, N. B. C., Mohiuddin, M., Shamsudin, S. F. F. B., \& Fazal, S. A. (2017). Entrepreneurial intention and startup preparation: A study among business students in Malaysia. Journal of Education for Business, 92(6), 296-314. https://doi.org/10.1080/08832323.2017.1365682

McClelland, D. C. (1961). The Achieving Society (2nd ed.). Princeton: Van Nostrand. https://doi.org/10.1037/14359-000

McGregor, J., \& Tweed, D. (2000), Women managers and business owners in New Zealand. Women in Management: Current Research Issues, 2, 40-52. https://doi.org/10.4135/9781446219775.n4

Memon, N. A., Makhdoom, T. R., Shah, G. M., \& Tunio, G. (2020). Entrepreneurial intention of business students in Pakistan: motivations and obstacles. Sarhad Journal of Management Sciences, 6(2), 311-324.

Minton, A. A. (2006). SMEs in Bangladesh. CACCI Journal, l(1).

Moustafa, L., \& Refaat, A. (2016). Entrepreneurial intention, motivations and constraints in times of depression and crisis: The case of Egyptian Tourism and Hotel Management undergraduates. In Proceedings of EuroCHRIE 2016 Conference (p. 31). 
Neneh, B. N. (2014). An assessment of entrepreneurial intention among university students in Cameroon. Mediterranean Journal of Social Sciences, 5(20), 542. https://doi.org/10.5901/mjss.2014.v5n20p542

Nunnally, J. C., \& Bernstein, I. H. (1994). Psychometric theory (3rd ed.) New York: McGrawHill.

Ooi, Y. K., \& Ahmad, S. (2012). A Study among University Students in Business Start-Ups in Malaysia: Motivations and Obstacles to Become Entrepreneurs. International Journal of Business and Social Science, 3(19), 181-192.

Pihie, Z. A. L. (2009). Entrepreneurship as a career choice: An analysis of entrepreneurial self-efficacy and intention of university students. European Journal of Social Science, 9(2), 338-349.

Pittaway, L., \& Cope, J. (2007). Entrepreneurship education. A systematic review of the evidence. International Small Business Journal, 25(5), 479-510. https://doi.org/10.1177/0266242607080656

Pruett, M., Shinnar, R., Toney, B., Llopis, F., \& Fox, J. (2009). Explaining entrepreneurial intentions of university students: A cross-cultural study. International Journal of Entrepreneurial Behaviour and Research, 15(6), 571-594. https://doi.org/10.1108/13552550910995443

Quddus, M., \& Rashid, S. (2000). Entrepreneurship and Economic Development: The remarkable story of Garment Export from Bangladesh. The University Press Limited, Dhaka.

Reynolds, P., Bosma, N., Autio, E., Hunt, S., De Bono, N., \& Servais, I. (2005). Global Entrepreneurship Monitor: Data collection design and implementation 1998-2003. Small Business Economics, 24(3), 205-231. https://doi.org/10.1007/s11187-005-1980-1

Rwigema, H., \& Venter, R. (2004). Advanced entrepreneurship (3rd ed.). Cape Town, Oxford University Press

Sandhu, M., Sidique, S., \& Riaz, S. (2011), Entrepreneurship barriers and entrepreneurial inclination among Malaysian postgraduate students. International Journal of Entrepreneurial Behaviour \& Research, 17(4), 428-449. https://doi.org/10.1108/13552551111139656

Scherer, R. F., Brodzinsky, J. D., \& Wiebe, F. A. (1991). Examining the relationship between personality and entrepreneurial career preference. Entrepreneurship and Regional Development, 3(1), 195-206. https://doi.org/10.1080/08985629100000013

Schlaegel, C., Engle, R. L., Dimitriadi, N., \& Taureck, P. C. (2015). Why not now? Triggers and barriers of new venture creation: a meta-analysis and multinational comparison of entrepreneurs' perspectives. International Journal of Entrepreneurial Venturing, 7(3), 227-250. https://doi.org/10.1504/IJEV.2015.071482

Sesen, H., \& Pruett, M. (2014). The impact of education, economy and culture on entrepreneurial motives, barriers and intentions: a comparative study of the United States and Turkey. Journal of Entrepreneurship, 23, 231-261. https://doi.org/10.1177/0971355714535309

Shamim, M. U. (2008). Building women in business: A situation analysis of women entrepreneurs in Bangladesh. Bangladesh Women Chamber of Commerce and Industry, Dhaka, 17.

Sharma, L., \& Madan, P. (2014). Effect of Individual factors on youth entrepreneurship - a study of Uttarakhand State, India. Journal of Global Entrepreneurship Research, 2(3), 1-17. https://doi.org/10.1186/2251-7316-2-3

Sidrat, S., Amouri, A., Boujelbene, Y., \& Boudabbous, S. (2016). Entrepreneurship in Tunisia: Obstacles. International Journal of Humanities and Social Science Invention, 5(4), 60-67.

Sitaridis, I., \& Kitsios, F. (2019). Entrepreneurship as a career option for information technology students: Critical barriers and the role of motivation. Journal of the Knowledge Economy, 10(3), 1133-1167. https://doi.org/10.1007/s13132-018-0519-z

Stamboulis, Y., \& Barlas, A. (2014). Entrepreneurship education impact on student attitudes. The International Journal of Management Education, 12, 365-373. https://doi.org/10.1016/j.ijme.2014.07.001

Still, L. V., \& Soutar, G. N. (2001). Generational and Gender Differences in the Start-up Goals and Later Satisfaction of Small Business Proprietors. Australia and New Zealand Academy of Management (ANZAM), Auckland.

Summary of the UGC Annual Report. (2019). University Grand Commission of Bangladesh. UGC publication number -215 . 
Swierczek, F., \& Ha T. T. (2003). Motivation, Entrepreneurship and Performance of SMEs in Vietnam. Journal of Enterprising Culture, 11(1), 47-68. https://doi.org/10.1142/S0218495803000044

Thanh, L., Hau, D., Huyen, N., Linh, N., Doanh, D., \& Nga, N. (2020). The effects of internal and external barriers on Vietnamese students' entrepreneurial intention. Management Science Letters, 10(2), 381-390. https://doi.org/10.5267/j.msl.2019.8.032

Turker, D., \& Selcuk, S, S. (2009). Which factors affect entrepreneurial intention of university students? Journal of European Industrial Training, 33(2), 142-159. https://doi.org/10.1108/03090590910939049

Van Gelderen, M., Brand, M., Van Praag, M., Bodewes, W., \& Van Gils, A. (2008). Explaining entrepreneurial intention by means of the theory of planned behavior. Career Development International, 13(6), 538-559. https://doi.org/10.1108/13620430810901688

Vesalainen, J., \& Pihkala, T. (2000). Entrepreneurial identity, intention and the effect of the push-factor. International Journal of Entrepreneurship, 3(2), 145-151.

Wong, M., \& Choo, S. (2009). Entrepreneurial Intention: Trigger and barrier to new venture creation in Singapore. Singapore Management Review, 28(2), 47-64.

Yamane, T. (1967). Statistics, An Introductory Analysis (2nd ed). New York: Harper and Row.

Zimmerman, M. A., \& Chu, H. N. (2013). Motivation, Success and Problems of Entrepreneurs in Venezuela. Journal of Management Policy and Practice, 14(2), 76-90.

\section{Copyrights}

Copyright for this article is retained by the author(s), with first publication rights granted to the journal.

This is an open-access article distributed under the terms and conditions of the Creative Commons Attribution license (http://creativecommons.org/licenses/by/4.0/). 